\title{
AGT M235T Polymorphism and Arterial Hypertension in Patients with Chronic Obstructive Pulmonary Disease
}

\author{
Marushchak $\mathrm{M}^{1^{*}}$, Maksiv $\mathrm{K}^{2}$, Krynytska $\mathrm{I}^{1}$ \\ ${ }^{I}$ Department of Functional and Laboratory Diagnostics, I. Horbachevsky Ternopil State Medical \\ University, 46001 Ternopil, Ukraine; ${ }^{2}$ Department of Medical Rehabilitation, I. Horbachevsky \\ Ternopil State Medical University, 46001 Ternopil, Ukraine;
}

\begin{abstract}
Background: Chronic obstructive pulmonary disease (COPD) represents an important public health challenge. It is a major cause of chronic morbidity and mortality throughout the world. Arterial hypertension (AH) is considered one of the principal COPD-associated comorbidities.
\end{abstract}

Objective: The study was aimed to assess the role of angiotensinogen (AGT) gene polymorphism in occurrence of $\mathrm{AH}$ in patients with COPD.

Methods: The study was conducted among 96 patients of them, Group 1 (25 individuals with COPD), Group 2 (23 individuals with AH), Group 3 (28 individuals with COPD and AH). The control group consisted of the 20 healthy subjects. I/D genotypes of AGT were determined by polymerase chain reaction amplification. Plasma AGT activity was determined photometrically by a commercially available kit.

Results: The results of the study have not demonstrated any significant impact of alleles of AGT genes on occurrence of such disease as COPD, AH and combinations thereof. However, analysis of odds ratio has demonstrated the presence of a trend towards a protective role of the $\mathrm{M}$ allele of the AGT gene concerning occurrence of COPD, $\mathrm{AH}$ and their combinations $(\mathrm{OR}=0.90, \mathrm{OR}=0.71$ and $\mathrm{OR}=0.56$, respectively). At the same time, the presence of the T allele of the AGT gene may increase the risk for occurrence of the above mentioned disease $(\mathrm{OR}=1.11, \mathrm{OR}=1.4$ and $\mathrm{OR}=1.79$, respectively).

Conclusion: The study suggests that the presence of T allele of the AGT gene at position 235 of the peptide chain both in homozygous and heterozygous state may increase the risk for $\mathrm{AH}$ in patients with COPD.

Keywords: Chronic obstructive pulmonary disease, Arterial hypertension, Angiotensinogen gene, Polymerase chain reaction.

\section{Introduction}

Chronic obstructive pulmonary disease (COPD) represents an important public health challenge and is a major cause of chronic morbidity and mortality throughout the world. COPD is currently the fourth leading cause of death in the world but is projected to be the $3^{\text {rd }}$ leading cause of death by $2020 .^{1,2}$ COPD is a complex respiratory disorder, which affects the course and development of some concomitant diseases; this makes COPD a systemic disorder. ${ }^{3}$ In COPD, comorbidities substantially affect the quality of life of patients, the frequency of exacerbations and life expectancy. ${ }^{4} \mathrm{~A}$ study by Vanfleteren et al has shown that $97.7 \%$ of patients with COPD had one or more comorbidities and $53.5 \%$ of the patients were diagnosed with four or more concomitant diseases. ${ }^{5}$

"Correspondence: Prof. Mariya Marushchak, I. Horbachevsky Ternopil National Medical University, Ternopil, Ukraine;

e-mail: marushchak@tdmu.edu.ua; ORCID:0000-0001-6754-0026
The most common comorbidities include anxiety/depression, cardiovascular disease (CVD), pulmonary hypertension, metabolic syndrome, diabetes, osteoporosis and gastroesophageal reflux disease. ${ }^{6-8}$

As expected, the most significant correlation was found between COPD and CVDs, which prevalence is a global health problem that leads to impaired quality of life and shortens life expectancy. ${ }^{9}, 10$ Arterial hypertension (AH) is part of CVDs that symbolise the highest proportion of disease-related mortality causes such as cerebral vascular accident and acute myocardial infarction, reaching about two-fifths of the adult population in developed countries. ${ }^{11} \mathrm{AH}$ is considered one of the principal COPD-associated comorbidities.

A population study has shown hypertension to be the highest prevalence comorbidity in patients with 
COPD among the 82 studied comorbidities $(24 \%){ }^{12}$ Similar results were reported in KNHANES V (Korean National Health and Nutrition Examination Survey) study, where only hypertension and history of pulmonary tuberculosis were independently associated with COPD among different 15 comorbidities. ${ }^{13}$ Another study shows that COPD is found in 25\% of patients with cardiovascular disease. ${ }^{14}$ Comorbidity analysis suggests the need for active strategies looking for correlations between COPD and the incidence of hypertension.

Both hypertension and COPD are genetically determined conditions with multiple genes, combinations of genes, inter-gene interactions and epigenetic processes responsible for their occurrence. When adverse genetic and external factors combine, a disease is formed. ${ }^{15,16}$ Most genetic studies of either AH or COPD focus on one disease only. However, taking into account the pathogenetic relationships between the diseases at the molecular level, it is the study of genetic basis of comorbid conditions that constitutes importance.

The data obtained in other study suggest that polymorphism of the angiotensin-converting enzyme (ACE) gene is related to development of $\mathrm{AH}$ in patients with COPD. ${ }^{17}$

Thus, the aim of this study was to establish the role of polymorphism of the angiotensinogen gene in occurrence of arterial hypertension in patients with chronic obstructive pulmonary disease.

\section{Materials and Methods}

The study consisted of 96 patients admitted to the Ternopil University Hospital. Patients were stratified, in three groups: Group 1 (25 patients with COPD), Group 2 (23 patients with $\mathrm{AH}$ ), Group 3 (28 patients with $\mathrm{COPD}+\mathrm{AH})$. The control group consisted of the 20 healthy subjects.

Male patients 40 to 60 years of age at screening with a diagnosis of COPD and/or AH were included in the study. Informed consent form signed by patients prior to their participation in any study-related procedures. COPD was diagnosed according to Order 555 of $\mathrm{MoH}$ of Ukraine dated June 27, 2013 and according to the guidelines published by American Thoracic Society and European Respiratory Society. ${ }^{\mathrm{xx}}$ Airway obstruction was assessed using GOLD classification, 2008. The study enrolled COPD patients with moderate (Stage 2) airway obstruction (FEV1 $=50$ $79 \%$ ). The diagnosis of Stage II AH was made according to Order 384 of $\mathrm{MoH}$ of Ukraine dated
May 24, 2012. Left ventricular hypertrophy was confirmed by an electrocardiogram. There were no significant differences across patient groups in terms of age and gender. All patients had been informed about the conduct of the study and had provided their written consent.

Patients with bronchial asthma, $\alpha 1$-antitrypsin deficiency, active tuberculosis, lung cancer, significant bronchiectasis, sarcoidosis, pulmonary fibrosis, interstitial lung disease; signs and symptoms of clinically significant neurological, psychiatric, renal, hepatic, immunological, gastrointestinal and urogenital disorders, musculoskeletal conditions, disorders of the skin and sensory organs, endocrine disorders (uncontrolled diabetes or thyroid disease) or uncontrolled hematological disease, unstable liver disease, unstable or life-threatening heart disease, cancer patients not completely disease-free for a minimum of 5 years and any drug, substance or alcohol abuse were excluded from the study.

Sampling of venous blood for genotyping was performed under sterile conditions into $2.7 \mathrm{~mL}$ Monovettes with potassium salt of ethylenediaminetetraacetic acid (EDTA) as an anticoagulant; the samples were frozen and stored at $-20^{\circ} \mathrm{C}$. Molecular genetic studies were performed with extraction of DNA and with use of polymerase chain reaction and further analysis for the length of restriction fragments. DNA was extracted from peripheral blood leukocytes with a standard salt precipitation method. Genotyping for the AGT M235T was performed using polymerase chain reaction (PCR)-based restriction fragment length polymorphism (RFLP). The primers used were 5'GATGCGCACAAGGTCCT-GTC-3' (Forward) and 5'-CAGGGTGCTGTCCAC-ACTGG ACCCC-3' (reverse). The PCR products were digested with $3 \mathrm{U}$ of Tth111I (Fermentas), and the fragments were separated on a $3 \%$ agarose gel containing ethidium bromide and visualised with UV light. To assess genotyping reliability, it was performed double sampling RFLP-PCR in more than $20 \%$ of the samples and found no differences. ${ }^{18}$

Statistical data analysis was carried out using STATISTICA 7.0 software. Assessment of genotypes of the selected sample for conformity to general population sample was guided by the Hardy-Weinberg principle. The observed frequencies and the expected frequencies calculated from the following expression: $\mathrm{p}^{2}+2 \mathrm{pq}$ $+q^{2}=1$ (Hardy-Weinberg equilibrium) were compared using Pearson chi-square, $\chi^{2}$. In case of 
probability value $p>0.05$, a null hypothesis of equal samples was accepted, i.e. that the selected sample was equivalent to the general population.

Comparative analysis of frequency tables was performed using Pearson Chi-Square, $\chi^{2}$ and Fisher exact $p$, two-tailed (in cases when expected frequencies of individual parameters did not exceed 5).

To assess the impact of the factor (the presence of a certain genotype or an allele of a gene) on occurrence of the disease odds ratio (OR) was calculated and its $95 \%$ confidence interval $(95 \%$ CI) and probability value, $p$.

\section{Results}

The frequency distribution of polymorphic genotypes of the gene encoding angiotensinogen and assessment of compliance with the HardyWeinberg population equilibrium were carried out in groups of patients with COPD, $\mathrm{AH}$ and with COPD $+A H$ combination. A deviation from the Hardy-Weinberg equilibrium was found in the group of patients with COPD due to a lower rate of heterozygotes than theoretically expected (table I).

Table I: Hardy-Weinberg equilibrium of the AGT gene M/T polymorphism in COPD, AT and their combination

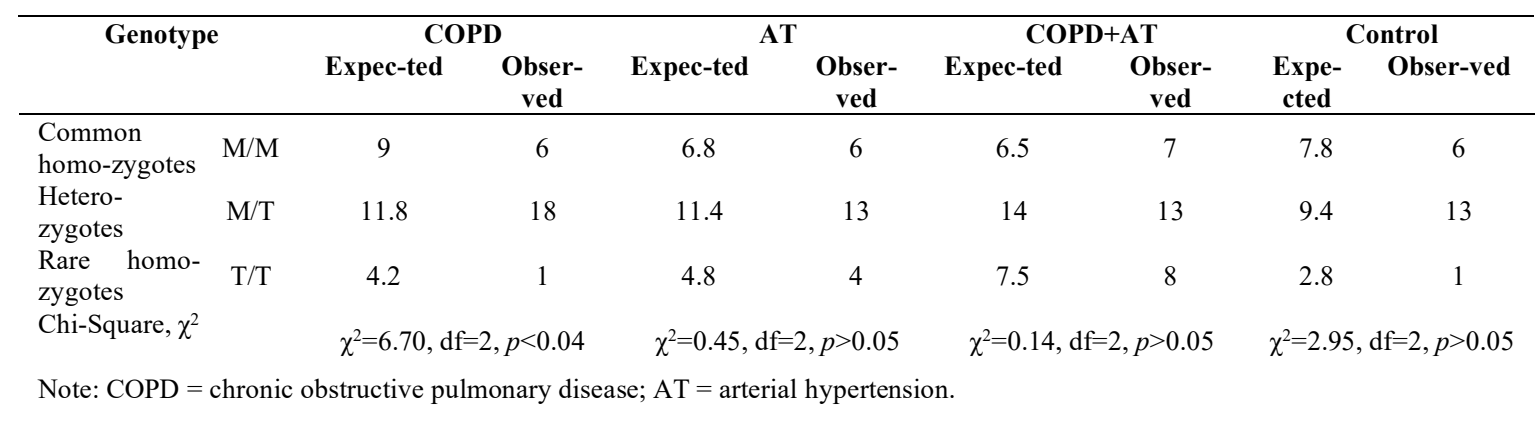

The deviation from the Hardy-Weinberg equilibrium in the group of patients with COPD is potentially attributable to the heterogeneity of the patient population. The frequencies of the genotype responsible for the $\mathrm{M} / \mathrm{T}$ polymorphism of the AGT gene in the control group and in groups 2 and 3 were not found to deviate significantly from the Hardy-Weinberg equilibrium $(p>0.05)$ (table 1). The respective frequencies for the genotypes of the AGT gene were as follows: $24.0 \%$ for $\mathrm{M} / \mathrm{M}, 75.0 \%$ for $\mathrm{M} / \mathrm{T}$ and $1.8 \%$ for $\mathrm{T} / \mathrm{T}$ in test group 1 with COPD; $26.1 \%$ for M/M, $56.5 \%$ for $\mathrm{M} / \mathrm{T}$ and $17.4 \%$ for $\mathrm{T} / \mathrm{T}$ in Group 2 with $\mathrm{AH} ; 25.0 \%$ for $\mathrm{M} / \mathrm{M}, 46.4 \%$ for $\mathrm{M} / \mathrm{T}$ and $28.6 \%$ for $\mathrm{T} / \mathrm{T}$ in Group 3 with $\mathrm{COPD}+\mathrm{AH}$ and $30.0 \%$ for $\mathrm{M} / \mathrm{M}, 65.0 \%$ for $\mathrm{M} / \mathrm{T}$ and $5.0 \%$ for $\mathrm{T} / \mathrm{T}$ in the control group (table II).

Table II: Genotype frequencies of the AGT gene M/T polymorphism in COPD, in AT and in COPD + AT

\begin{tabular}{|c|c|c|c|c|c|c|c|c|}
\hline \multirow{2}{*}{$\begin{array}{l}\text { Genotype } \\
\text { frequencies }\end{array}$} & \multicolumn{2}{|c|}{ COPD } & \multicolumn{2}{|c|}{ AT } & \multicolumn{2}{|c|}{ COPD+AT } & \multicolumn{2}{|c|}{ Control } \\
\hline & $n$ & $\%$ & $n$ & $\%$ & $\mathbf{n}$ & $\%$ & $n$ & $\%$ \\
\hline $\mathrm{M} / \mathrm{M}$ & 6 & 24.0 & 6 & 26.1 & 7 & 25.0 & 6 & 30.0 \\
\hline $\mathrm{M} / \mathrm{T}$ & 18 & 72.0 & 13 & 56.5 & 13 & 46.4 & 13 & 65.0 \\
\hline $\mathrm{T} / \mathrm{T}$ & 1 & 4.0 & 4 & 17.4 & 8 & 28.6 & 1 & 5.0 \\
\hline $\begin{array}{l}\text { Fisher exact } \\
p, \quad \text { two- } \\
\text { tailed } \\
\text { (disease/ } \\
\text { control } \\
\text { group) }\end{array}$ & \multicolumn{2}{|c|}{$p=0.75$} & \multicolumn{2}{|c|}{$p=0.76$} & \multicolumn{2}{|c|}{$p=0.25$} & \multicolumn{2}{|c|}{ - } \\
\hline $\begin{array}{l}\text { Note: COPD } \\
\text { hypertension. }\end{array}$ & $\operatorname{chr}$ & nic obs & & pulm & & sease; & & rterial \\
\hline
\end{tabular}

In the COPD group, the established distribution was AGT M allele $(60.0 \%)$ and AGT T allele (40.0\%); the respective distributions were $54.3 \%$ and $45.7 \%$ in the $\mathrm{AH}$ group; $48.2 \%$ and $51.8 \%$ in the COPD+AH group and $62.5 \%$ and $37.5 \%$ in the control group, with no significant differences across test groups and the control group (table III).

Table III: Allele frequencies of the AGT gene M/T polymorphism in COPD, $\mathrm{AH}$ and their combination

\begin{tabular}{|c|c|c|c|c|c|c|c|c|}
\hline \multirow{2}{*}{$\begin{array}{c}\text { Allele } \\
\text { frequency }\end{array}$} & \multicolumn{2}{|c|}{ COPD } & \multicolumn{2}{|c|}{$\mathbf{A H}$} & \multicolumn{2}{|c|}{$\begin{array}{c}\text { COPD+A } \\
\text { H }\end{array}$} & \multicolumn{2}{|c|}{ Control } \\
\hline & $\mathbf{n}$ & $\%$ & $\mathbf{n}$ & $\%$ & $\mathbf{n}$ & $\%$ & $\mathbf{n}$ & $\%$ \\
\hline AGT & 3 & 60. & 2 & 54. & \multirow{2}{*}{27} & 48. & 2 & 62. \\
\hline M allele & 0 & 0 & 5 & 3 & & 2 & 5 & 5 \\
\hline AGT & 2 & 40. & 2 & 45. & \multirow{2}{*}{29} & 51. & 1 & 37. \\
\hline $\mathrm{T}$ allele & 0 & 0 & 1 & 7 & & 8 & 5 & 5 \\
\hline $\begin{array}{l}\text { Pearson } \\
\text { Chi- }\end{array}$ & & & & & & & & \\
\hline $\begin{array}{l}\text { Square, } \\
\chi^{2} \\
\text { (disease } \\
\text { / control } \\
\text { group) }\end{array}$ & \multicolumn{2}{|c|}{$\begin{array}{c}\chi^{2}=0.06 \\
\mathrm{df}=1 \\
p=0.81\end{array}$} & \multicolumn{2}{|c|}{$\begin{array}{c}\chi^{2}=0.58 \\
\mathrm{df}=1 \\
p=0.44\end{array}$} & \multicolumn{2}{|c|}{$\begin{array}{c}\chi^{2}=1.92 \\
\mathrm{df}=1 \\
p=0.17\end{array}$} & & \\
\hline \multicolumn{9}{|c|}{$\begin{array}{l}\text { Notes: } \mathrm{COPD}=\text { chronic obstructive pulmonary disease; } \mathrm{AH}= \\
\text { arterial hypertension. }\end{array}$} \\
\hline
\end{tabular}

The results of the study have demonstrated absence of a statistically significant relationship between the factor (presence of $\mathrm{M} / \mathrm{T}$ alleles) and occurrence of disease $(p>0.05)$ (table IV). 
Table IV: Odds ratio for alleles in different study groups

\begin{tabular}{cccccccc}
\hline & \multicolumn{5}{c}{ Alleles } \\
\cline { 2 - 8 } Group & \multicolumn{3}{c}{ AGT Mallele } & \multicolumn{4}{c}{ AGT T allele } \\
\cline { 2 - 8 } & OR & $\mathbf{9 5 \%}$ & $\boldsymbol{p}$ & OR & $\mathbf{9 5 \%}$ & $\boldsymbol{p}$ \\
& & CI & & & CI & \\
\hline COPD & 0.90 & $0.38-$ & $>0.05$ & 1.11 & $0.47-$ & $>0.05$ \\
& & 2.11 & & & 2.61 & \\
AH & 0.71 & $0.3-$ & $>0.05$ & 1.4 & $0.59-$ & $>0.05$ \\
& & 1.69 & & & 3.32 & \\
COPD+AH & 0.56 & $0.24-$ & $>0.05$ & 1.79 & $0.78-$ & $>0.05$ \\
& & 1.28 & & & 4.09 & \\
\hline
\end{tabular}

Assessment of the probability value as part of analysis of odds ratio has demonstrated absence of influence of a certain genotype on occurrence of the disease $(p>0.05)$ (table V).

The results of the study had not demonstrated any significant impact of alleles of AGT genes on occurrence of such disease as COPD, $\mathrm{AH}$ and combinations thereof. However, analysis of odds ratio has demonstrated the presence of a trend towards a protective role of the $\mathrm{M}$ allele of the AGT gene concerning occurrence of COPD, AH and their combinations $(\mathrm{OR}=0.90, \mathrm{OR}=0.71$ and $\mathrm{OR}=0.56$, respectively).

Table V: Odds ratio for genotypes in different study groups

\begin{tabular}{ccccccc}
\hline \multirow{3}{*}{ Group } & \multicolumn{6}{c}{ Genotype } \\
\cline { 2 - 7 } & \multicolumn{2}{c}{$\mathbf{M} / \mathbf{M}$} & \multicolumn{2}{c}{$\mathbf{M} / \mathbf{T}$} & \multicolumn{2}{c}{ T/T } \\
\cline { 2 - 7 } & $\mathbf{O R}$ & $\mathbf{9 5 \%}$ & $\mathbf{O R}$ & $\mathbf{9 5 \%}$ & $\mathbf{O R}$ & $\mathbf{9 5 \%}$ \\
$\mathbf{C I}$ & & $\mathbf{C I}$ & & $\mathbf{C I}$ \\
\hline COPD & 0.7 & $0.20-$ & 1.3 & $0.39-$ & 0.7 & $0.05-$ \\
& 4 & 2.77 & 8 & 4.92 & 9 & 13.5 \\
$\mathrm{AH}$ & 0.8 & $0.22-$ & 0.7 & $0.20-$ & 4.0 & $0.41-$ \\
& 2 & 3.13 & 0 & 2.41 & 0 & 39.18 \\
COPD $+\mathrm{A}$ & 0.7 & $0.22-$ & 0.4 & $0.14-$ & 7.6 & $0.87-$ \\
$\mathrm{H}$ & 8 & 2.81 & 7 & 1.52 & 0 & 66.67
\end{tabular}

Note: $p$ coefficient for OR $p>0.05$ in all cases.

At the same time, the presence of the $\mathrm{T}$ allele of the AGT gene might increase the risk for occurrence of the above mentioned disease $(\mathrm{OR}=1.11, \mathrm{OR}=1.4$ and $\mathrm{OR}=1.79$, respectively).

Table VI: A recessive model of the AGT gene inheritance in combination of COPD and $\mathrm{AH}$

\begin{tabular}{|c|c|c|c|c|c|c|}
\hline \multirow{2}{*}{$\begin{array}{l}\text { Genotyp } \\
\text { es }\end{array}$} & $\begin{array}{c}\text { COPD+ } \\
\text { AH }\end{array}$ & $\begin{array}{c}\text { Contr } \\
\text { ol } \\
\end{array}$ & \multirow{2}{*}{$\chi^{2}$} & \multirow{2}{*}{$p$} & \multirow{2}{*}{$\begin{array}{l}\mathbf{O} \\
\mathbf{R}\end{array}$} & \multirow{2}{*}{$\begin{array}{r}95 \% \\
\text { CI }\end{array}$} \\
\hline & $\%$ & $\%$ & & & & \\
\hline $\begin{array}{l}\mathrm{M} / \mathrm{M}+\mathrm{M} \\
/ \mathrm{T} \\
\text { genotype }\end{array}$ & 71.4 & 95.0 & 4.2 & 0.0 & $\begin{array}{c}0.1 \\
3\end{array}$ & $\begin{array}{c}0.01- \\
1.15\end{array}$ \\
\hline $\begin{array}{l}\mathrm{T} / \mathrm{T} \\
\text { genotype }\end{array}$ & 28.6 & 5.0 & 5 & 4 & $\begin{array}{c}7.6 \\
0\end{array}$ & $\begin{array}{l}0.87- \\
66.67\end{array}$ \\
\hline
\end{tabular}

This is confirmed by a significant difference found when building a recessive inheritance model in combination of COPD and $\mathrm{AH}$ (table VI). In a dominant model of inheritance of the AGT gene in combination of COPD and $\mathrm{AH}$, no significant differences from the control group had been detected (the probability value for chi-square: $p>0.05$ ); however, in this setting there is also a trend towards increased probability of occurrence of disease in presence of the T allele (table VII). Therefore, the presence of the $\mathrm{T}$ allele (both in homozygous and heterozygous state) may increase the risk for the above mentioned diseases (table VI-VII).

Table VII: A dominant model of AGT gene inheritance in combination of COPD and AH

\begin{tabular}{lccccccc}
\hline \multirow{2}{*}{$\begin{array}{l}\text { Genotype } \\
\mathbf{s}\end{array}$} & $\mathbf{C O P D}+\mathbf{A H}$ & $\begin{array}{c}\text { Contro } \\
\mathbf{1}\end{array}$ & $\chi^{\mathbf{2}}$ & $\boldsymbol{p}$ & $\mathbf{O R}$ & $\mathbf{9 5 \%} \mathbf{C I}$ \\
\cline { 2 - 3 } & $\mathbf{\%}$ & $\mathbf{\%}$ & & & & \\
\hline $\begin{array}{l}\mathrm{M} / \mathrm{M} \\
\text { genotype }\end{array}$ & 25.0 & 30.0 & & 0.15 & 0.78 & $\begin{array}{c}2.22- \\
2.81\end{array}$ \\
$\begin{array}{l}\mathrm{M} / \mathrm{T}+\mathrm{T} / \mathrm{T} \\
\text { genotype }\end{array}$ & 75.0 & 70.0 & & 7 & 1.29 & $\begin{array}{c}0.36- \\
4.64\end{array}$ \\
\hline
\end{tabular}

In groups of subjects without combined disease (in the group of patients with COPD and in the group of patients with $\mathrm{AH}$ ), no significant differences were found in analysis of dominant and recessive types of inheritance for the AGT gene (M and T alleles) (in these cases, the probability value for $\chi^{2}$ square was $p>0.05$ ).

\section{Discussion}

COPD is a heterogeneous condition that has a single common denominator: chronic airflow obstruction. Because currently available treatments have minimal impact on disease progression, a strategy to prevent the development of COPD is a critical priority. Personal direct cigarette smoking is the most important single causal factor for developing COPD; however, only a small fraction of smokers develops a clinical presentation of COPD. ${ }^{19,20}$ Analysis of literature suggests that other risk factors biologically interact with cigarette smoking and potentiate the development of airflow obstruction: genetic factors, longstanding asthma, outdoor air pollution, secondhand smoke exposure, biomass smoke and indoor air pollution, occupational exposures, diet, and tuberculosis. ${ }^{21-25}$

Complications and comorbidities are an important consideration to take into account when managing the process of shaping the models of prevention, diagnosis and treatment of COPD. ${ }^{26}$ COPD is known to be associated with a large number of comorbid conditions. As expected, the most significant correlation was found between COPD 
and cardiovascular disease. Actually, COPD was found to be a predecessor of cardiovascular disease., ${ }^{9,27}$ Frequent combinations of and interactions between these conditions may be attributable to several causes due to presence of common links of pathogenesis. ${ }^{28}$ As a result of pulmonary tissue inflammation in COPD, molecules with proinflammatory, profibrous, procoagulant and vasoconstrictor effects are released into systemic circulation. These molecules are capable of modifying endothelial function, thereby creating conditions for a persistent elevation of blood pressure. ${ }^{29}$ On the other hand, hyperactivation of neurohormonal systems such as renin-angiotensin-aldosterone system (RAAS), which is typical for $\mathrm{AH}$, may be involved in pulmonary inflammation, as well as in remodeling of lung parenchyma and bronchioles. Via type 1 receptors in the lungs, angiotensin II promotes activation of immunocompetent cells and the discharge of proinflammatory cytokines; it also induces proliferation of fibroblasts and apoptosis of bronchial epithelium and activates the processes associated with oxidative stress. ${ }^{30}$

Polymorphisms of the genes encoding RAAS components were found in different populations. ${ }^{31-33}$ The angiotensinogen gene (AGT) is localised on the long arm of chromosome 1 in 1q42-q43 locus and contains 5 exons. In the $A G T$ gene, the best studied variants include the polymorphic M235T and T174M variants. The T174M (rs4762) polymorphism is characterized by a replacement of threonine with methionine at position 174 in the peptide chain, which is caused by a point replacement of cytosine with thymine at position 521 of the $A G T$ gene (C521T). The M235T (rs699) polymorphism is a replacement of methionine with threonine at position 235 of the peptide chain, which is caused by a point replacement of thymine with cytosine at position 704 of the $A G T$ gene (T704C). ${ }^{34}$ The polymorphic variant included in this study was the single-nucleotide replacement of thymine with cytosine at position 704 of the second exon of the angiotensinogen gene, which is leading to the Met $\rightarrow$ Thr change at position 235 of the final product (M235T).

The findings of this study suggest the absence of a significant impact of AGT alleles or AGT genes on occurrence of such disease as COPD, AH and their combination among the patients of the Ukrainian population. In another study conducted in Ukraine, which assessed haplotype frequencies depending on the studied polymorphic variants of the $A G T$ gene in different age groups of women with $\mathrm{AH}$, no significant differences compared to controls have likewise been detected. ${ }^{35}$ A study by Simonyte et al of the frequencies of AGT genotypes and alleles using a multivariate logistic regression analysis could not demonstrate any association between AGT M235T polymorphism and hypertension. ${ }^{36}$ Niu et al also found no association of AH with AGTM235T polymorphisms, even after adjustment for age, gender or severity of the disease. ${ }^{37}$ Likewise, Caulfield et al have not found any association with polymorphisms of the AGTM235T gene. ${ }^{38}$ However, according to the results obtained in a study by Mohana et al, the presence of $235 \mathrm{M} / 174 \mathrm{M}$ haplotype suggests an increased risk of $\mathrm{AH}$ in women. ${ }^{39}$ The first report on association of M235 T molecular variants with hypertension in Caucasians was presented by Jeunemaitre et al. ${ }^{40}$ In a study of M235T (T704C) polymorphism, Sethi et al have found that the presence of polymorphic alleles leads to a significant increase in angiotensin-I plasma levels, accompanied by an increase in angiotensin-II levels; therefore, this polymorphism is considered to be associated with hypertension. ${ }^{41}$ The results of the study by Kolovou et al suggest that only the frequency of the AGTM235T (rs699) variant was significantly different between patients with $\mathrm{AH}$ and controls. ${ }^{42}$ The results by Shamaa have shown a positive risk of $\mathrm{AH}$ in presence of $\mathrm{T}$ allele in a homozygous or heterozygous state, suggesting a relationship between the polymorphism of AGT genes (M235T) and risk for hypertension in Egyptian subjects. ${ }^{43}$ This is why some studies confirm the association between AGT polymorphism and AT while others disprove it.

The results of this study in a group of patients with COPD have shown a significant deviation from the Hardy-Weinberg equilibrium for the polymorphism of M235T AGT gene, which is consistent with the data by Ayada et al. ${ }^{44}$ The latter authors attributed such result to a gene drift, having assumed that the rare TT genotype was causing a gene drift in the COPD population. It is quite possible that the $\mathrm{T}$ allele is disappearing in the COPD population due to its negative impact, which can also be a sign of the correlation between the TT genotype and the development of COPD. In this study, interesting results have been obtained for analysis of odds ratio in combination of COPD and AH. These results demonstrated a trend towards a protective role of the $\mathrm{M}$ allele of the AGT gene concerning the occurrence of $\mathrm{COPD}, \mathrm{AH}$ and their combination, 
while the presence of the T allele of the AGT gene could increase the risk for these conditions. A study on the role of AGT polymorphism in occurrence of $\mathrm{AH}$ in COPD in Ukraine was conducted for the first time; virtually no data on this issue could be found in available literature. The majority of the studies relate to the association of I/D polymorphism of the ACE gene with the risk for COPD. ${ }^{45-47}$ It is worth noting that the DD genotype of ACE is generally associated with increased circulating and cellular levels of ACE and increased cardiovascular risk. ${ }^{48}$ There are data on association of AGT polymorphism (M235T) with right ventricular hypertrophy in patients with severe COPD. ${ }^{49}$

The present study had some limitations that should be considered in the interpretation of the results. The major limitation of this study was that the patients were not randomly selected, generating a potential selection bias. Therefore, it could not rule out the hypothesis that the patients evaluated do not represent the whole population of COPD patients in Ternopil region of Ukraine. However, the results reflect a more heterogeneous real-world population, representative of clinical practice.

\section{Conclusion}

The study findings suggest that the presence of $T$ allele of the angiotensinogen gene at position 235 of the peptide chain both in homozygous and heterozygous state may increase the risk for arterial hypertension in patients with COPD.

\section{Acknowledgments}

The authors would like to thank staff from Laboratory of Leading Biotechnology "NEOGEN" (Kyiv, Ukraine) for the help during PCR investigations.

Conflict of interest: The authors have no conflicts of interest to declare

Funding: No funding for this study

Ethical approval: Ternopil National Medical University (study No 03-187/4)

Submitted: $14^{\text {th }}$ July, 2019

Final revision received: $4^{\text {th }}$ March, 2020

Accepted: $19^{\text {th }}$ March, 2020

Published: $1^{\text {st }}$ December, 2020

\section{References}

1. Global Initiative for Chronic Obstructive Lung Disease. Pocket Guide to COPD Diagnosis, Management, and Prevention. A Guide for Health Care Professionals, 2017.

URL:goldcopd.org/wp-content/uploads/2016/12/ wms-GOLD-2017-Pocket-Guide.pdf
2. Pinto CR, Carlos MLA, Lindemberg AC, de Tupiná AA, Yamamura LLL, Santana SG, et al . Management of COPD within the Brazilian Unified Health Care System in the state of Bahia: an analysis of real-life medication use patterns. J Bras Pneumol. 2019;45:e20170194. DOI: 10.1590/1806-3713/e20170194.

3. Smith M, Wrobel J. Epidemiology and clinical impact of major comorbidities in patients with COPD. International Journal of COPD 2014; 9:871-88.

DOI: $10.2147 / C O P D . S 49621$

4. Putcha N, Puhan MA, Hansel NN, Drummond $\mathrm{MB}$, Boyd CM. Impact of co-morbidities on self-rated health in self-reported COPD: an analysis of NHANES 2001-2008. COPD. 2013;10: 324-32.

DOI: $10.3109 / 15412555.2012 .744963$

5. Vanfleteren LE, Spruit MA, Groenen M. Clusters of comorbidities based on validated objective measurements and systemic inflammation in patients with chronic obstructive pulmonary disease. Am J Respir Crit Care Med. 2013;187: 728-35. DOI: $10.1164 / \mathrm{rccm} .201209-1665$ OC

6. Kim J, Lee JH, Kim Y. Association between chronic obstructive pulmonary disease and gastroesophageal reflux disease: a national cross-sectional cohort study. BMC Pulm Med. 2013;13:51.

DOI: 10.1186/1471-2466-13-51

7. Hanania NA, Mullerova H, Locantore NW. Determinants of depression in the ECLIPSE chronic obstructive pulmonary disease cohort. Am J Respir Crit Care Med. 2011;183: 604-11. DOI: $10.1164 / \mathrm{rccm} .201003-0472 \mathrm{OC}$

8. de Lucas-Ramos P, Izquierdo-Alonso JL, Rodriguez-Gonzalez MJM. Chronic obstructive pulmonary disease as a cardiovascular risk factor. Results of a case-control study (CONSISTE study). Int $\mathrm{J}$ Chron Obstruct Pulmon Dis. 2012;7:679-86.

DOI: $10.2147 /$ COPD.S36222

9. Caram LM, Ferrari R, Naves CR, Coelho LS, Vale SA, Tanni SE, et al. Risk factors for cardiovascular disease in patients with COPD: mild-to-moderate COPD versus severe-to-very severe COPD. J Bras Pneumol. 2016;42: 179-84. DOI: $10.1590 / \mathrm{S} 1806-37562015000000121$

10. Marushchak M, Krynytska I, Mikolenko A, Andreychyn Y, Bodnar Y, Chornomydz I. Chronic heart failure causes osteopathy or is osteopathy a factor in development of chronic heart failure? AJPCR. 2018;11: 111-15. DOI: 10.22159/ajpcr.2018.v11i1.17532 
11. Pinto IC, Martins D. Prevalence and risk factors of arterial hypertension: a literature review. J Cardiovasc Med Ther. 2017;1: 1-7.

URL:www.alliedacademies.org/articles/prevalen ce-and-risk-factors-of-arterial-hypertension-aliterature-review-7926.html

12. Baty F, Putora PM, Isenring $B$, Blum $T$, Brutsche M. Comorbidities and burden of COPD: a population based case-control study. PLoS One. 2013;8:e63285.

DOI: 10.1371/journal.pone.0063285

13. Jo YS, Choi SM, Lee J, Park YS, Lee SM, Yim JJ, et al. The relationship between chronic obstructive pulmonary disease and comorbidities: a crosssectional study using data from KNHANES 20102012. Respir Med. 2015;109: 96-104.

DOI: $10.1016 /$ j.rmed.2014.10.015

14. Onishi K, Yoshimoto D, Hagan GW, Jones PW. Prevalence of airflow limitation in outpatients with cardiovascular diseases in Japan. Int $\mathbf{J}$ Chron Obstruct Pulmon Dis. 2014;9:563-68. DOI: $10.2147 /$ COPD.S59962

15. Berdnikova NG, Bujkin SV, Bukreeva EB. Genetic of bronchopulmonary diseases. M: Atmosfera. 2010; 160-61.

16. Ehret GB, Munroe PB, Rice KM. Genetic variants in novel pathways influence blood pressure and cardiovascular disease risk. Nature. 2011;478: 103-09.

DOI: $10.1038 /$ nature 10405

17. Marushchak M, Maksiv K, Krynytska I. ACE gene I/D polymorphism and arterial hypertension in patients with COPD. Pneumologia. 2019; 68:114-19.

18. Imen T, Grissa MH, Boubaker H, Beltaief K, Messous S, Tounsi N, et al. AGT M235t polymorphism and heart failure in a cohort of Tunisian population: diagnostic and prognostic value. Int J Clin Exp Med. 2015;8:16346-351. PMID: 26629155

19. Zimermann PJ, Teixeira PJ, Nogueira MF. COPD: more treatment will translate to better breathing. Will it? J Bras Pneumol. 2019;45:e20190037 DOI: $10.1590 / 1806-3713 / \mathrm{e} 20190037$

20. Wu X, Yuan B, Lopez E, Bai C, Wang X. Gene polymorphisms and chronic obstructive pulmonary disease. J Cell Mol Med. 2014;18: 15-26. 10.1111/jcmm.12159

21. Eisner MD, Anthonisen N, Coultas D, Kuenzli N, Perez-Padilla R. An Official American Thoracic Society Public Policy Statement: Novel Risk Factors and the Global Burden of Chronic
Obstructive Pulmonary Disease. Am J Respir Crit Care Med. 2010;182: 693-718. DOI: $10.1164 / \mathrm{rccm} .200811-1757 \mathrm{ST}$

22. Fedortsiv O, Brozek GM, Luchyshyn N, Kubey I, Lawson JA, Rennie DC, Zejda JE. Prevalence of childhood asthma, rhinitis, and eczema in the Ternopil region of Ukraine - Results of BUPAS study. Advances in Medical Sciences. 2012;57: 282-89.

DOI: $10.2478 / \mathrm{v} 10039-012-0034-6$

23. Gilowska I, Kasper L, Bogacz K. Impact of Matrix Metalloproteinase 9 on COPD Development in Polish Patients: Genetic Polymorphism, Protein Level, and Their Relationship with Lung Function. Bio Med Research International. 2018; 1-12. DOI: $10.1155 / 2018 / 6417415$.

24. Hardin M, Silverman EK. Chronic obstructive pulmonary disease genetics: a review of the past and a look into the future. J COPD F. 2014;1: 33-46. DOI: $10.15326 /$ jcopdf.1.1.2014.0120

25. Kukkonen MK, Tiili E, Vehmas T, Oksa P, Piirilä P, Hirvonen A. Association of genes of protease-antiprotease balance pathway to lung function and emphysema subtypes. BMC Pulm Med. 2013; 13:1-10.

DOI: $10.1186 / 1471-2466-13-36$

26. Ehteshami-Afshar S, FitzGerald JM, DoyleWaters MM, Sadatsafavi M. The global economic burden of asthma and chronic obstructive pulmonary disease. Int $\mathrm{J}$ Tuberc Lung Dis. 2016;20: 11-23.

DOI: $10.5588 /$ ijtld.15.0472

27. Calverley PM, Scott S. Is airway inflammation in chronic obstructive pulmonary disease (COPD) a risk factor for cardiovascular events? COPD. 2006;3: 233-42.

DOI: $10.1080 / 15412550600977544$

28. Fabbri LM, Luppi F, Beghé B, Rabe KF. Complex chronic comorbidities of COPD. Eur Respir J. 2008;31:204-12.

DOI: $10.1183 / 09031936.00114307$

29. Miller J, Edwards LD, Agustí A. Comorbidity, systemic inflammation and outcomes in the ECLIPSE cohort. Respir Med. 2013;107: 1376-84. DOI: 10.1016/j.rmed.2013.05.001

30. Shrikrishna D, Astin R, Kemp PR, Hopkinson NS. Renin-angiotensin system blockade: a novel therapeutic approach in chronic obstructive pulmonary disease. Clin Sci (Lond). 2012;123: 487-98.

DOI: $10.1042 / \mathrm{CS} 20120081$ 
31. Levitskiy SN, Pervukhina OA, Bebyakova NA. The role of gene polymorphisms of the reninangiotensin system in the formation of cardiovascular pathology. Vestnik SAFU. Biomedical Sciences. 2016;4:30-39.

32. Hollá L, Văsků A, Znojil V, Sisková L, Vácha J. Association of 3 gene polymorphisms with atopic diseases. J Allergy Clin Immunol. 1999; 103:702-08.

DOI: $10.1016 / \mathrm{s} 0091-6749(99) 70246-0$

33. Turgut S, Akın F, Akc1lar R, Ayada C, Turgut G. Angiotensin converting enzyme I/D, angiotensinogen M235T and AT1-R A/C1166 gene polymorphisms in patients with acromegaly. Mol Biol Rep. 2011;38:569-76. DOI: $10.1007 / \mathrm{s} 11033-010-0142-y$

34. Tsymbalyuk VI, Vasilyeva IG, Kostiuk MR, Chopik NG, Galanta OS, Tsyubko OI, et al. Investigation of the association between ACE, AGT and FGB gene polymorphisms and risk of early onset of atherothrombotic ischemic stroke in ukrainian caucasian population. INJ. 2016;8: 20-26. DOI: 10.22141/2224-0713.8.86.2016.90907

35. Fishchuk LY. Influence of gene polymorphisms of the renin-angiotensin system on the risk of hypertension in women. Odessa Medical Journal. 2013;5: 26-30.

36. Simonyte S, Kuciene R, Medzioniene J, Dulskiene V, Lesauskaite V. Renin-angiotensin system gene polymorphisms and high blood pressure in Lithuanian children and adolescents. BMC Medical Genetics. 2017;18:100.

DOI: $10.1186 / \mathrm{s} 12881-017-0462-\mathrm{z}$

37. Niu T, Yang J, Wang B, Chen W, Wang Z, Laird $\mathrm{N}$, et al. Angiotensinogen gene polymorphisms M235T/T174M: no excess transmission to hypertensive Chinese. Hypertension. 1999;33:698-702.

DOI: 10.1161/01.HYP.33.2.698

38. Caulfield M, Lavender P, Farrall M, Munroe P, Lawson M, Turner $\mathrm{P}$, et al. Linkage of the angiotensinogen gene to essential hypertension. N Engl J Med. 1994;330:1629-33. DOI: 10.1056/NEJM199406093302301

39. Mohana VU, Swapna N, Surender RS, Vishnupriya S, Padma T. Gender-related association of AGT gene variants (M235T and T174M) with essential hypertension - a casecontrol study. Clinical and Experimental Hypertension. 2012;34:38-44.

DOI: $10.3109 / 10641963.2011 .618207$

40. Jeunemaitre X, Soubrier F, Kotelevtsev YV, Lifton RP, Williams CS, Charru A, et al. Molecular basis of human hypertension: role of angiotensinogen. Cell. 1992;71:169-80.

\section{DOI: 10.1016/0092-8674(92)90275-h}

41. Sethi AA, Nordestgaard BG, Grønholdt ML, Steffensen R, Jensen G, Tybjærg-Hansen A. Angiotensinogen single nucleotide polymorphisms, elevated blood pressure, and risk of cardiovascular disease. Hypertension. 2003;41: $1202-11$.

DOI: 10.1161/01.HYP.0000072334.34433.17

42. Kolovou V, Lagou E, Mihas C, Vasiliki G, Katsiki N, Kolovou G. Angiotensinogen (AGT) M235T, AGT T174M and angiotensin-1converting enzyme (ACE) I/D gene polymorphisms in essential hypertension: effects on ramipril efficacy. The Open Cardiovascular Medicine Journal. 2015;9:118-26.

DOI: $10.2174 / 1874192401509010118$

43. Shamaa MM. Fouad H, Haroun M, Hassanein M, Hay MAA. Association between the Angiotensinogen (AGT) gene (M235T) polymorphism and essential hypertension in Egyptian patients. The Egypt Heart J. 2015;67: 1-5. DOI: 10.1016/j.ehj.2013.10.001

44. Ayada C, Toru Ü, Genç O, Şahin S, Turgut S, Turgut G. Angiotensinogen gene M235T and angiotensin II-type 1 receptor gene $\mathrm{A} / \mathrm{C} 1166$ polymorphisms in chronic obtructive pulmonary disease. International journal of clinical and Experimental Medicine. 2015;8:4521-26. PMID: 26064378

45. Kon SS, Jolley CJ, Shrikrishna D. ACE and response to pulmonary rehabilitation in COPD: two observational studies. BMJ Open Respir Res. 2017;4: e000165.

DOI: 10.1136/bmjresp-2016-000165

46. Simsek S, Tekes S, Oral D. The insertion/deletion polymorphism in the ACE gene and chronic obstructive pulmonary disease. Genet Mol Res. 2013;12: 1392-98.

DOI: $10.4238 / 2013$.April.25.10

47. Pabst S, Theis B, Gillissen A. Angiotensinconverting enzyme I/D polymorphism in chronic obstructive pulmonary disease. Eur J Med Res. 2009;14: 177-81.

DOI: $10.1186 / 2047-783 x-14-s 4-177$

48. Kanazawa H, Otsuka T, Hirata K, Yoshikawa J. Association between the angiotensin converting enzyme gene polymorphisms and tissue oxygenation during exercise in patients with COPD. CHEST. 2002;121: 697-701. DOI: $10.1378 /$ chest.121.3.697

49. Wu X, Yuan B, López E, Bai C, Wang X. Gene polymorphisms and chronic obstructive pulmonary disease. J Cell Mol Med. 2014;18: 15-26.

DOI: $10.1111 /$ jcmm. 12159 